\title{
Jagoda Przybysz*
}

iD https://orcid.org/0000-0003-3697-3325

\section{DOŚWIADCZENIE MIGRACJI W BIOGRAFIACH MIGRANTÓW MIESZKAJĄCYCH W LODZI}

\begin{abstract}
Abstrakt. Artykuł stanowi jakościową analizę 32 biografii imigrantów mieszkających w Łodzi od minimum 3 lat, w teoretycznej ramie life course studies. Jednostkowe historie cudzoziemców analizowane są w kontekście ich życiowych wyborów, następowania kolejnych faz życia, wpływu warunków społecznych (w tym ich sieci społecznych) na podjęcie decyzji o migracji i przeprowadzce do innego kraju (jeszcze przebywając w kraju pochodzenia) oraz sprzyjających i niesprzyjających czynników decydujących o pozostaniu w Polsce, kontynuowaniu edukacji, znalezieniu pracy i założeniu rodziny.
\end{abstract}

Słowa kluczowe: life course, przebieg życia, migracje, przyczyny migracji, skutki migracji, imigranci, Łódź.

\section{Wprowadzenie}

Perspektywa cyklu życia, której przedmiotem jest badanie indywidualnych historii życia, pozwala zrozumieć, jak wcześniejsze wydarzenia, warunki społeczno-ekonomiczne, posiadane zasoby indywidualne i cechy osobnicze wpływają na podejmowane przez jednostkę decyzje i jej kolejne doświadczenia życiowe.

Ujęcie life course, podkreślając związek między życiem jednostek a kontekstem historycznym, uwarunkowaniami społeczno-politycznymi oraz warunkami gospodarczymi, w którym ich życie ma miejsce, koncentruje się na zmianach społecznych i związanych z nimi losach członków rodziny, zauważając, że ,życie toczy się niezależnie od tego, a więź definiuje droga, za pośrednictwem której zmienia się historia rozgrywana z biegiem czasu" (Elder, Caspi 1990: 221). Podejście to ma swoje początki w pionierskich badaniach Thomasa i Znanieckiego, dotyczących migracji i adaptacji polskich chłopów w Europie i w Stanach Zjednoczonych (Thomas, Znaniecki 1958). Przedmiotem tych badań były zmiany w życiu chłopów polskich migrujących w poszukiwaniu lepszych warunków życia.

${ }^{*}$ Mgr, Katedra Socjologii, Wydział Socjologii i Pedagogiki, Szkoła Główna Gospodarstwa Wiejskiego, ul. Nowoursynowska 166,02-787 Warszawa, e-mail: jagoda_przybysz@sggw.pl 
Perspektywa life course studies wykorzystywana jest obecnie w badaniach mających na celu ustalenie, jak wcześniejsze wydarzenia w jednostkowym życiu - edukacja i wychowanie, doświadczenie zawodowe, wyuczone i powielone wzorce zachowań - wpływają na podejmowane późniejsze decyzje życiowe, dotyczące wchodzenia w relacje, zawierania związków, posiadania potomstwa oraz strategii stosowanych na rynku pracy.

Realizowane w latach 30. i 40. XX wieku badania podłużne koncertowały się na znaczących momentach przejścia w życiu jednostek (key transitions in individual lives): podjęciu pierwszej pracy i jej charakterze, pełnieniu ról społecznych, zawarciu związku małżeńskiego lub przejściu do rodzicielstwa. Badania te realizowane najczęściej przez demografów i socjologów rodziny nazwane zostały studiami cyklu życia (life cycle) (Glick 1988), a duża ich część dotyczyła trendów rodzinnych, małżeństw zróżnicowanych religijnie i rasowo w aspekcie zmian społeczno-ekonomicznych i stabilności rodziny, średniej wieku wchodzenia w pierwsze związki małżeńskie i powszechności rozwodów (Edmonston 2013).

Dopiero lata 50. ubiegłego wieku zaowocowały rozwojem badań podłużnych, poprzez wprowadzenie do nich nowych wątków, m.in.: związków partnerskich poza małżeństwem i rodzin niepełnych oraz biografii analizowanych w szerszym, historycznym kontekście. To właśnie te studia nad przebiegiem życia uzyskały nowy status koncepcji badawczej perspektywy cyklu życia (life course perspective) (Edmonston 2013). Jest ona szczególnie cenna do badań nad migrantami i ich rodzinami oraz przyczynami i skutkami podejmowanych decyzji migracyjnych zarówno dla nich samych, jak i ich najbliższych.

\section{Przebieg życia w ujęciu socjologicznym}

Edmonston (2013), postrzegając całe życie jako proces, począwszy od narodzin i kończąc na śmierci, koncentruje się na indywidualnych wyborach jednostek, zakładając, iż na ich przyszłe decyzje wpływają aktualne wybory, podejmowane także pod wpływem wcześniejszych wydarzeń. Przy czym proces ten odbywa się z udziałem rodziny, innych osób, z którymi jednostka pozostaje w relacjach, a umiejscowiony jest w kontekście historycznym, społecznym i polityczno-ekonomicznym.

W zależności od przyjętego stanowiska badawczego, różnie jest definiowany związek z indywidualnym doświadczeniem czasu historycznego, wspólnoty doświadczeń kohort demograficznych i pokoleń w rozumieniu nadanym przez Karla Mannheima (Marshall, Mueller 2003).

Fragmentaryzacja badań nad przebiegiem życia, wyróżnianie i opisywanie odmiennych faz i wymiarów procesów oraz obecna już od lat 80 . destandaryzacja stanowiły skutek racjonalnego i indywidualnego podejścia badawczego. Przywołując pojęcia wprowadzone przez Anthony'ego Giddensa, Ulricha Becka i Eli- 
zabeth Beck-Gernsheim: choice biography, reflexive biography czy do it yourself biography, akcentujemy w badaniach wybrane wydarzenia z życia jednostki, które zaprowadziły ją do stanu obecnego (Grotowska-Leder, Rek-Woźniak, Kudlińska 2016).

Perspektywa cyklu życia jest charakteryzowana przez jednego z pionierów w badaniach nad przebiegiem życia Glena Eldera (Elder 1985; 1994) przy użyciu takich kategorii jak: trajektorie, przejścia, punkty zwrotne i czas. Każda z tych czterech zmiennych - samodzielnie lub w połączeniu - bez względu na dyscyplinę badawczą, jest obecna w badaniach nad cyklem życia. Trajektorie (trajectories) są długimi wzorcami zmian i stabilności. W odniesieniu do przebiegu kariery zawodowej mogą opisywać długość zatrudnienia w wybranym sektorze, śledzić historię zatrudnienia oraz wskazywać okresy wzmożonej mobilności zawodowej. Przejścia (transitions) są wydarzeniami, które mogą powodować zmiany w życiu i relacjach jednostki. Często wiążą się one ze zmianą statusu lub tożsamości, zarówno osobistej, jak i społecznej, a tym samym otwierają możliwości zmiany zachowania jednostki (Mortimer, Shanahan 2002). Przejścia we wczesnym etapie życia mogą powodować dalsze konsekwencje dla trajektorii kształtującej późniejsze wydarzenia, doświadczenia i przejścia. Przykładem może być posiadanie potomstwa w wieku dorastania (Furstenberg, Brooks-Gunn, Morgan 1987, za: Mortimer, Shanahan 2002), odbywanie obowiązkowej służby wojskowej (Sampson, Laub 1996, za: Mortimer, Shanahan 2002), ale też migracja do innego kraju. Następstwa tych wydarzeń odczuwane są już przez całe dalsze życie. Z kolei punkty zwrotne (turning points) to główne przejścia, które powodują gwałtowną zmianę trajektorii przebiegu życia danej osoby. Wiążą się z istotną zmianą kierunku życia zarówno subiektywną, jak i obiektywną (Mortimer, Shanahan 2002). Przykładem takiego wydarzenia jest np. zamieszkanie w nowym kraju. Natomiast czas (timing) odnosi się do kontekstu historycznego lub cech charakterystycznych w danym okresie. Może zarówno nawiązywać do szerokiego kontekstu (np. II wojna światowa lub okres kryzysu gospodarczego) lub dotyczyć pewnych wydarzeń w życiu jednostki, mających miejsce w określonym wieku (np. ukończenie szkoły lub ślub). Te same zdarzenia lub doświadczenia mogą w różny sposób wpływać na jednostki w zależności od tego, w którym momencie życia występują (George 1993, za: Mortimer, Shanahan 2002). Sam sens nadawany poszczególnym wydarzeniom może się zmienić w czasie osiągania dorosłości i kolejnych stadiów rozwojowych (Wheaton 1990).

Imigranci to grupa ludzi, których doświadczeniem są znaczące zmiany zachodzące w życiu zarówno po, ale także przed migracją. Często momenty przejścia są dla nich punktami zwrotnymi, a trajektorie poszczególnych obszarów życia w zależności od historycznego czasu i miejsca, odwzorowują zachodzące społecznie procesy. Perspektywa cyklu życia pozwala w takich przypadkach na ujawnienie $\mathrm{i}$ analizę powiązań między wydarzeniami $\mathrm{w}$ doświadczeniach i ich skutkami oraz na interpretowanie przejawianych zachowań - społecznie akceptowanych lub anormalnych - i ich wpływu na późniejsze życie jednostki. 


\section{Perspektywa przebiegu życia w badaniach migracji}

Dotychczasowe badania nad masowym przemieszczaniem się ludności najczęściej koncentrowały się wokół decyzji i prognoz migracji (Bonifazi i in. 2008; Raymer, Willekens 2008, za: Wingens, Windzio, de Valk, Aybek 2011). Dopiero niedawno większy nacisk położono na trajektorie integracji imigrantów (Bernhardt i in. 2007; de Valk 2006; Kalmijn, van Tubergen 2006; Kulu, Milewski 2007; Lesthaeghe 2002, za: Wingens, Windzio, de Valk, Aybek 2011). Występuje jednak różnica między perspektywą przebiegu życia stosowaną w badaniach populacji a tym podejściem w socjologicznych badaniach przebiegu życia. W demografii przebieg życia początkowo był głównie stosowany w kategoriach stopniowania wieku i osiągania kolejnych faz cyklu życia, podczas gdy w socjologii - w kategoriach następujących po sobie sekwencji uczestnictwa jednostek w życiu społecznym, w dostępie do edukacji czy rynku pracy, w zakładaniu rodziny itp. wraz z upływającym czasem i wiekiem jednostki. Ponieważ sekwencje te są osadzone w strukturach społecznych, podejście do przebiegu życia w ujęciu socjologicznym silniej koncentruje się na złożonej, wzajemnej zależności między aktorami biograficznymi a ustaleniami instytucjonalnymi, według których społeczeństwa organizują życie (Wingens, Windzio, de Valk, Aybek 2011).

Zdaniem Jasso (2003), w procesie migracji występują zawsze trzej główni aktorzy: migrant (jako sprawczy podmiot podejmowanych decyzji migracyjnych); osoby pozostające w miejscu jego pochodzenia (rodzina, przyjaciele, znajomi) oraz osoby w miejscu przemieszczenia. Autor w analizie migracji w perspektywie przebiegu życia podkreśla aktywną role wskazanych trzech podmiotów w procesie decyzyjnym (stosunek społeczeństwa przyjmującego, realia formalno-prawne umożliwiające migrację i wsparcie społeczeństwa wysyłającego), wszyscy również doświadczają jej skutków (pomoc materialna dla osób w społeczeństwie wysyłającym, przepływ informacji, pomysłów i nowych możliwości oraz doświadczanie korzyści jako pracodawcy, konsumenci, pracownicy itp.).

Biografie jednostek w perspektywie przebiegu życia w badaniach nad migrantami mogą być za Glenem Elderem (Elder 1994; 1998) analizowane w czterech obszarach:

- życie jednostki i czas historyczny (lives and historical time);

- czas życia poszczególnych osób (timing of lives);

- życie powiązane z innymi (linked lives);

- sprawczość jednostki (human agency).

Poszczególne kohorty imigrantów, w zależności od kraju pochodzenia i czasu historycznego, wybierają strategie migracyjne regulowane przepisami prawa - kraju przyjmującego i wysyłającego - oraz faktycznymi możliwościami ich realizacji w danym momencie historycznym, kształtowanymi także przez politykę migracyjną danego kraju. 
Czas życia poszczególnych osób, oznacza nie tylko wiek rozwojowy, odnosi się również do oczekiwanego czasu, w którym powinny wystąpić pewne zdarzenia lub momenty przejścia, które służą jako punkty odniesienia do oceny wystąpienia ważnych wydarzeń w życiu (Edmonston 2013).

Powiązane ze sobą życia to koncepcja, która podkreśla współzależność poszczególnych żyć z innymi i ich wzajemny na siebie wpływ, w szczególności w analizie więzi rodzinnych, przyjacielskich i towarzyskich (Edmon ston 2013). Doświadczenia rodzinne, wzorce interpersonalne, silne więzi z przyjaciółmi oraz z osobami w miejscu pracy (w przypadku części imigrantów) odgrywają ważną rolę $\mathrm{w}$ momencie podjęcia decyzji migracyjnej, jak i bezpośrednio po przeprowadzce. Często występują modele rodzin w sytuacji rozłąki migracyjnej, choć w oddzieleniu przestrzennym nadal stanowią model analiz połączonych ze sobą żyć, ale dodatkowo w transnarodowym charakterze.

Pojęcie sprawczości działań podejmowanych przez jednostkę w perspektywie cyklu życia polega na tym, że jednostki rozwijają swoje życie w kontekście wielu aktywności społecznych i ekonomicznych. Już od dziecięcych lat na rozwój jednostki wpływają przyjaciele, rodzina, szkoła, ośrodki kultu religijnego i inne kluczowe instytucje i organizacje życia codziennego. Ważnym aspektem wydaje się więc umiejętne zidentyfikowanie, zdefiniowanie i zrozumienie roli jaką pełnią w życiu człowieka, inne, znaczące osoby oraz rozmiar posiadanych sieci społecznych, ich siła, częstotliwość i czas trwania kontaktów (Edmon ston 2013). W podejmowaniu decyzji o podjęciu migracji często towarzyszą inni aktorzy życia społecznego migranta, którzy w sposób pośredni lub bezpośredni potrafią wpływać na proces decyzyjny jak i motywację jednostki. Również całokształt posiadanych kompetencji, umiejętności, kwalifikacji (zawodowych i językowych) nabywany $\mathrm{w}$ trakcie edukacji formalnej i nieformalnej lub w kontaktach z osobami trzecimi, kształtuje gotowość do podejmowania aktywności i wyzwań we własnym życiu.

Perspektywa przebiegu życia z powodzeniem może uwzględniać kontekst migracji w badaniach całej populacji, ale badacze postulują potrzebę stworzenia osobnych klasyfikacji przy włączaniu tego kontekstu. Według Edmonstona (Edmonston 2013) ważnymi obszarami tego typu analiz są wtedy: polityka i imigracja; religia; sytuacja rodzinna; zatrudnienie i wykonywany zawód; ukończone szkoły i znajomość języka; dochód; zamieszkiwanie i ruchliwość oraz zdrowie. Przy czym zbiór ten nie powinien być zamknięty, a dodatkowo analizowany w połączeniu z sześcioma etapami cyklu życia - dzieciństwem, adolescencją, wczesnym okresem dorosłości, średnim okresem dorosłości, późnym okresem dorosłości i okresem starości. Warto przyjrzeć się bliżej tym obszarom badań.

Polityka/imigracja. Przybycie migranta do nowego kraju pobytu wiążę się z potrzebą edukacji z zakresu obowiązujących regulacji prawnych, dotyczących statusu pobytu, warunków zatrudnienia, możliwości powrotu do kraju pochodzenia, swobody przemieszczania się, uzyskania obywatelstwa kraju przyjmującego, a także partycypacji w życiu społecznym i politycznym (udziału w wyborach, zakładaniu stowarzyszeń i partii politycznych). 
Religia. Imigranci często mają odmienne przekonania i praktyki religijne niż ogół członków społeczeństwa przyjmującego. Kontakty z osobami o innych wyznaniach religijnych, poszukiwanie ośrodków praktykowanego kultu religijnego w kraju przybycia, ale także proces zmiany religii (czy radykalizacja lub liberalizacja przekonań) stanowią ważny wątek badawczy, bowiem sytuacje te wśród migrantów częściej niż w populacji ogółem mogą określać trajektorie życia lub stanowić jego punkty zwrotne.

Rodzina. Badanie rodzin migrantów jest niezbędne dla pełnego zrozumienia procesów integracji migrantów we wszystkich płaszczyznach życia. Analizy procesów socjalizacji w rodzinach migrantów drugiego pokolenia, kontaktów międzypokoleniowych (z dziadkami, dalszą rodziną w sytuacji mieszkania: wspólnego/osobnego, czasowego/stałego w kraju przybycia/pochodzenia/innym niż kraj pochodzenia). Kluczowe dla procesów adaptacyjnych są również decyzje o zawarciu małżeństwa (w ramach tej samej grupy etnicznej, językowej i religijnej, z obywatelem kraju przybycia/innym imigrantem w tym kraju), posiadanie potomstwa i kwestie opieki nad nimi, rozwód; kontakty z rodziną bliższą i dalszą.

Zatrudnienie/zawód. Eksplorowanie kwestii związanych z zatrudnieniem (w szczególności z pierwszą pracą) w kraju przybycia jest ważna, bowiem często pierwsze doświadczenia zawodowe w nowym miejscu determinują późniejszą karierę zawodową migranta, wpływając na dalsze losy jego i jego rodziny. Analizy dotyczące rynku pracy powinny również obejmować wymagania jakie są w kraju przyjmującym, umiejętności i kwalifikacje migrantów i przebieg ich wcześniejszego zatrudnienia (w kontekście pracy poniżej/powyżej kwalifikacji, zgodnej/ niezgodnej z wykształceniem, zawodem wyuczonym), czasem bezrobocia oraz strategie poszukiwania pracy.

Edukacja/język. Oprócz potrzeby nostryfikacji dyplomów lub/i ukończenia specjalnych kursów i szkoleń uznawanych w kraju przybycia, ważny jest poziom znajomości języka kraju goszczącego. Wykonywana praca często wymaga również znajomości języka kraju pochodzenia (czasem podstawą zatrudnienia jest natywny język migranta, a codziennej komunikacji służy język używany w kraju przybycia) oraz znajomość innych języków obcych.

Dochód. Wysokość wynagrodzenia/dochodu powinna być analizowana w oparciu o zasady obowiązujące w kraju przebywania z uwzględnieniem statusu społeczno-ekonomicznego. Dość często migranci systematycznie partycypują w utrzymaniu dwóch gospodarstw domowych w związku z pozostaniem rodziców/ rodzeństwa w kraju pochodzenia.

Zamieszkiwanie/ruchliwość. Ten wymiar określa wzorce zamieszkania i prowadzenia gospodarstwa domowego (wspólne zamieszkiwanie, mieszkanie migracyjne, wynajmowanie lokalu/domu, zakup mieszkania/domu, inwestycja w inne nieruchomości) jak i ruchliwości w rozumieniu kontaktów z miejscem pierwszego pobytu, które wynikają z przywiązania do niego (do mieszkania/ domu, dzielnicy, miasta, regionu, kraju). Szersze rozumienie dotyczyć może ru- 
chliwości w obrębie kraju goszczącego lub planów na przyszłość - powrotu do kraju pochodzenia lub przeprowadzki w inne miejsce.

Zdrowie. Kategoria ta analizowana jest w zakresie dostępu do instytucji opieki zdrowotnej kraju przyjmującego, świadczenia obowiązkowych składek ubezpieczenia społecznego, korzystania z niepublicznej opieki zdrowotnej oraz kondycji zdrowotnej migranta (choroby wrodzone, nabyte).

Jak podkreśla Edmonston (2013) ważnym elementem jest kwestia nieodwracalności konsekwencji podjętych decyzji - nawet po powrocie do kraju pochodzenia „epizod emigracji” będzie miał swoje skutki w przebiegu życia danego człowieka. Ewentualna przyszła migracja może również wpływać na obecne zachowanie, ponieważ osoba, która planuje w przyszłości wyjazd stały lub tymczasowy, podejmuje inne decyzje niż ktoś, kto nie zamierza migrować.

\section{Doświadczenia migrantów mieszkających w Lodzi}

Podstawę empiryczną rozważań stanowią 32 indywidulane, pogłębione wywiady przeprowadzone $\mathrm{z}$ migrantami pracującymi od minimum trzech lat w Łodzi (2017-2019). Biografie tych cudzoziemców analizowane są z uwzględnieniem kontekstu podjęcia decyzji migracyjnej oraz ośmiu obszarów życia wymienionych przez Edmonstona (Edmonston 2013), w tym wzorów spędzania czasu wolnego. Dyspozycje do pogłębionego wywiadu swobodnego dotyczyły wszystkich obszarów funkcjonowania migranta w nowej rzeczywistości, a budowana przez badacza strategia rozmowy prowadziła do swobodnej narracji respondenta na temat:

- sytuacji poprzedzającej podjęcie decyzji migracyjnej (kiedy, z jakich przyczyn, czy decyzja została podjęta samodzielnie czy za namową osób trzecich, jaka była sytuacja edukacyjna, zawodowa, rodzinna i ekonomiczna, jakie były perspektywy życia i plany w kraju pochodzenia, dlaczego została podjęta decyzja o wyjeździe, dlaczego do Polski i regionu łódzkiego);

- przebiegu procesu migracyjnego (starania się o wizy/pozwolenia na pracę/ aplikowania na studia; legalizacji pobytu, załatwiania formalności związanych z wyjazdem i organizacją pobytu, udziału osób trzecich w procedurze, wsparcia instytucjonalnego, sieci społecznej migranta);

- pobytu w Polsce i w Łodzi od przyjazdu do czasu przeprowadzenia wywiadu (podjęcia pierwszego zatrudnienia, nawiązywania pierwszych relacji: w miejscu pracy i poza nim, z przedstawicielami diaspory, z innymi migrantami, z Polakami; sytuacji rodzinnej, mieszkaniowej, zawodowej, materialnej, życia religijnego, kulturalnego, obywatelskiego, strategii życiowych w mieście, spędzania czasu wolnego, planów na przyszłość, załatwiania spraw formalnych).

Czas trwania przeciętnego wywiadu wynosił 1 godzinę 27 minut, przy czym najkrótsza rozmowa trwała 43 minuty (z powodu niskich kompetencji językowych 
respondenta), najdłuższa -3 godziny 38 minut. Wywiady przeprowadzano w języku polskim lub angielskim, w zależności od preferencji rozmówcy.

W badaniu wzięło udział 23 mężczyzn i 9 kobiet. Mężczyźni pochodzili z: Maroka (1), Włoch (2), Sudanu (1), Ukrainy (4), Niemiec (1), Tunezji (1), Turcji (2), Szwecji (1), Szwajcarii (2), Kamerunu (1), Francji (1), Holandii (1), Nikaragui (1), Kolumbii (1), Indii (2) i Azerbejdżanu (1). Kobiety jako kraj pochodzenia podawały: Maroko (1), Ukrainę (4), Białoruś (3), Łotwę (1). Respondenci byli w wieku od 22 do 58 lat. W większości deklarowali wykształcenie średnie (techniczne lub zawodowe) i wyższe (na poziomie licencjatu lub magisterium). Dwóch z respondentów legitymowało się wykształceniem podstawowym.

Rodzaj posiadanego pozwolenia na pobyt w momencie przybycia definiował główny motyw wyjazdu respondentów: $14 \mathrm{z}$ nich przyjechało do Polski w celach edukacyjnych korzystając $\mathrm{z}$ wizy studenckiej i dość szybko podjęło pracę (najdłuższy okres bezrobocia wynosił 2 lata - IDI_8_26 lat). Większa część rozmówców wskazała na motyw ekonomiczny (11) - ci legitymowali się czasowym pozwoleniem na pracę. Dwoje respondentów korzystało z Karty Polaka ${ }^{1}$ (IDI_12_29 lat; IDI_30_29 lat). Obecnie trzy osoby posiadają kartę stałego pobytu - jedna z nich rozpoczęła procedurę naturalizacji (IDI_1_22 lata), a jedna z osób badanych ma obywatelstwo polskie (IDI_9_43 lata).

Większość respondentów należy do kategorii młodych dorosłych $(22)^{2}$. Tylko jeden rozmówca jest przedstawicielem kategorii późnej dorosłości, aktywnie prowadzącym życie zawodowe i rodzinne (pozostaje w nieformalnym związku z Polką młodszą o 16 lat, prowadzi własną firmę usługową, IDI_25_58 lat). Analizie poddano życiorysy badanych migrantów uwzględniając omówione w literaturowej części rozważań podstawowe konteksty perspektywy cyklu życia.

\section{Czas historyczny i sytuacja ekonomiczno-społeczna, a decyzja o wyjeździe z kraju pochodzenia}

Respondenci z Turcji (IDI_27_25 lat, IDI_7_28 lat) początkowo przyjechali do Polski w celach edukacyjnych w ramach programu Erasmus, kontynuowali studia w Polsce i głównie ze względu na sytuację polityczną ${ }^{3}$ w kraju pochodzenia zdecydowali się na emigrację. Konflikt zbrojny na Ukrainie (kwiecień

${ }^{1}$ Karta Polaka to dokument potwierdzający przynależność do Narodu Polskiego. Posiadaczowi Karty przysługują uprawnienia wynikające z ustawy o Karcie Polaka, uchwalonej przez Sejm Rzeczypospolitej Polskiej 7 września 2007 r. Otrzymanie Karty Polaka nie oznacza przyznania obywatelstwa polskiego, przyznania prawa do osiedlania się na terytorium Rzeczypospolitej Polskiej ani prawa przekraczania bez wizy granic Rzeczypospolitej Polskiej.

2 Por. Grotowska-Leder, Rek-Woźniak, Kudlińska (2016).

${ }^{3}$ Wskazywali na próbę puczu wojskowego w 2016 r., niestabilną sytuację gospodarczą, rosnące bezrobocie i prześladowania opozycji. 
2016 r.) zapoczątkował masowy napływ ludności z terenów objętych działaniami wojennymi i stopniowe dostosowywanie prawa polskiego regulującego zatrudnianie cudzoziemców i jego późniejsze nowelizacje (uproszczone oświadczenia powierzenia pracy obcokrajowcowi i zgłoszenia do ubezpieczenia społecznego). Sprzyjające warunki zatrudnienia, pozytywna opinia wcześniejszych migrantów z Ukrainy o Polsce jako kraju pobytu oraz wysokie bezrobocie lub bardzo niskie płace na Ukrainie, to wskazywane przez większość respondentów motywy wyjazdu z Ukrainy. Jedna z rozmówczyń (IDI_31_27 lat), zdecydowała się na wyjazd w obawie o swoje życie, chociaż deklarowała, iż w innej sytuacji gospodarczo-politycznej kraju nigdy nie odważyłaby się na taki krok. Również respondentki z Białorusi (IDI_32_29 lat; IDI_24_25 lat; IDI_12_29 lat) swoje decyzje migracyjne motywowały złą sytuacją polityczną, ekonomiczną i zawodową w kraju pochodzenia, chęcią poprawy własnej sytuacji materialnej oraz pozostawionej w kraju rodziny. Jedna z respondentek, przebywająca w Polsce dzięki Karcie Polaka (IDI_32_29 lat), wspominała, iż jej związki z Polską nie były silne w dzieciństwie, a tradycje i obyczaje kultywowano tylko w domu babki (z pochodzenia Polki). Zdecydowała się na wyjazd z kraju ze względu na narastające problemy ze znalezieniem zatrudnienia, poczucie braku perspektyw, ale także rozstanie z ówczesnym narzeczonym. Pod wpływem powyższych powodów postanowiła opuścić kraj w oparciu o przepisy repatriacyjne.

Ważną rolę podczas podejmowania decyzji migracyjnych odgrywało to, na jakim etapie życia była dana osoba. Dla znaczącej części respondentów był to moment przełomowy (ukończenie szkoły; podjęcie studiów; zawarcie małżeństwa i wspólnie podjęta decyzja o zmianie miejsca zamieszkania; rozwód; utrata dotychczasowej pracy). Dwoje respondentów wybierając Polskę jako kraj emigracji i podjęcia studiów, kierowało się przepisami pozwalającymi studentom na podjęcie zatrudnienia - sytuacja ekonomiczna ich rodziny w kraju pochodzenia wykluczała jakąkolwiek formę pomocy finansowej, szukali więc możliwości samodzielnego utrzymania się (IDI_3_27 lat; IDI_11_35 lat).

Wszyscy rozmówcy podczas badania deklarowali, że mają zatrudnienie, a ich pobyt usankcjonowany był kartą pobytu - na pobyt stały lub czasowy. Rozmówcy z Ukrainy i Białorusi wskazywali na szereg przeszkód o charakterze instytucjonalnym, na które napotkali podczas procedur legalizacji pobytu. Najczęstszymi problemami były: długi okres oczekiwania, kompetencje językowe pracowników polskich instytucji, nieznajomość języka polskiego przez cudzoziemców oraz niejasne przepisy.

Jest bardzo trudno w Urzędzie Wojewódzkim teraz z Ukraincami. To jest po prostu masakra. Jak chcesz kartę pobytu albo jakieś zezwolenia, to musisz czekać 2 miesiace, pót roku, do roku $i$ w ogóle. To jest po prostu katastrofa. I wtedy też nie możesz kraju opuścić. Tak samo jak chcesz tutaj zostać i pozałatwiać, żeby to wszystko szło do przodu, a wchodzisz do tego urzędu $i$ koniec. Opadaja ręce, nogi i idziesz stad [...] zależy jak do kogo podejdziesz, czasem chce pomóc i jest miła, a druga: rób co chcesz, oprócz Ciebie mam jeszcze 20 osób, jak do kogo 
pójdziesz. Jedna dziewczyna czeka miesiac, góra dwa miesiace, a ma taka sama paczkę dokumentów jak inna, ta dostaje odmowę, a tamta ma takie same dokumenty. Paczka dokumentów jest taka sama i nie wiadomo dlaczego (IDI_17_26 lat).

Ta sama firma, na jednym stanowisku pracujemy, jedna dostała, druga nie. A jak pójdziesz się pokłócić to $w$ ogóle do widzenia... U nas było identycznie. Jedna paczka poszła do jednego inspektora, druga do drugiego, no i wychodzi tak, że u mnie wszystko dobre, u męża nie. Ja przyszła z tymi paczkami i mówię, że mam dwie paczki dokumentów, jest wszystko identycznie, dlaczego tak, że ja dostałam, a on nie, Nie wiedza...podajesz papiery nie wiedza, czy potrzebny, czy nie, tylko PESEL niedtugo będą wołać, a nie możesz mieć składając dokumenty (IDI_18_28 lat).

\section{Sprawczości działań podejmowanych przez jednostkę w perspektywie cyklu życia}

Sprawczość działań podejmowanych przez jednostkę występuje w biografiach niemalże wszystkich respondentów. Często artykułowano potrzebę zmiany własnego życia jako jedyną szansę na poprawę swojej sytuacji w kraju pochodzenia.

Chciatem zmienić swoje życie [...] pochodzę z Neapolu, a życie nie byto tam tatwe, walki uliczne, narkotyki, alkohol...tak jest wszędzie na ulicy, jest jak chleb. Każdego dnia. A ja chciatem się zmienić. Przyjechatem do Polski za praca. 7 lat temu (IDI_16_25 lat).

Podjęta przez mężczyznę decyzja o wyjeździe i próba porzucenia dotychczasowego stylu życia, zaowocowała rozpoczęciem pierwszej w życiu pracy w Warszawie (praca na budowie, dzięki referencjom kolegi), a następnie przeprowadzką do Łodzi, po otrzymaniu kontraktu spawacza w jednej z łódzkich firm budowlanych.

Wśród przyczyn podejmowanych decyzji migracyjnych, szczególnie wśród respondentów przybyłych do Polski w oparciu o wizę studencką (14 rozmówców) oraz pozwolenie na pobyt stały (6 rozmówców), obserwuje się strategię definiowaną jako „podejmowanie podróży”, często związaną z wystąpieniem liminalnej fazy cyklu życia (van Genep 2006). Wchodzeniu w etap stającej się dorosłości (emerging adulthood) (Arnett 2004; 2007), często towarzyszy potrzeba wypróbowania własnych możliwości, poszukiwania tożsamości, skupienia się na własnych potrzebach, marzeniach i dążeniach, podejmowania nowych wyzwań (Arnett 2004).

Chciałem sam zdecydować co ze mna, kiedy byłam w domu rodzice zawsze mi mówili co mam robić, w końcu mogłem być samodzielny [...] było ciężko na początku, ale było warto. Wiem na ile mnie stać...i znam swoje limity (IDI_27_25 lat).

Kolejna z respondentek, przyjechała do Polski pod wpływem spotkania i nawiązania przyjaźni z pracującymi kiedyś w Łodzi osobami, mówi:

Polska bardzo mnie zmieniła. Musiałam poradzić sobie sama, wiedzieć jak się soba zaopiekować, załatwić formalności, dowiedzieć się wszystkiego, zaczać od nowa. I byłam z tym zupetnie sama. Musisz zostać zajęta, możesz albo pogrążć się w żalu, albo zainwestować w siebie, rozwijać się, uczyć, uprawiać sporty, spotykać z przyjaciólmi (IDI_22_30 lat). 
Opisane w literaturze przedmiotu typy osobowości społecznych migrantów (por. Thomas, Znaniecki 1957; Paleczny 2002), definiują nastawienie do aktu migracji, czasu jej trwania i potencjalnej ciągłości. Wieczni tułacze (Paleczny 2002), poszukiwacze (Wrzesień 2009) czy stosujący strategię ,intencjonalnej nieprzewidywalności" (Grabowska-Lusińska, Okólski 2009), skupiają się na rozwoju osobistym, pozostają otwarci na nowe możliwości, żyją bez zobowiązań, są ambitni i chętnie podejmują wyzwania. Pytana o plany na przyszłość rozmówczyni mówi:

Nie wiem co będzie jutro, nie wiem co będzie za rok, żyję dzisiaj i teraz. Może wyjadę gdzieś dalej, może znowu wyjdę za maż [śmiech]; a może wygram na loterii [...] jeśli dostanę gdzieś ofertę pracy to pomyślę, czemu nie...juz zaczynałam nowe życie, to będzie mi łatwiej (IDI_22_30 lat).

27 letni mieszkaniec Azerbejdżanu nauczył się języka tureckiego, oglądając telewizję satelitarną i dzięki temu wyjechał do szkoły średniej znajdującej się po tureckiej stronie Cypru. Swoje dalsze losy opisuje następująco:

Życie tam [Cypr] było bardzo drogie, pracowatem, gdzie mogłem, a jak już miałem pozwolenie to wyjeżdżałem na wakacje do Londynu - podszkolić język angielski i zarobić. Znudziło mi się już tam mieszkanie, szukatem czegoś nowego. Życie w Londynie jest drogie, w Polsce byto taniej, to zacząłem się uczyć polskiego ['śmiech] (IDI_3_27 lat).

W wieku 22 lat, z podstawową znajomością języka polskiego, podjął studia informatyczne, rok później pracę w jednej z łódzkich korporacji. Pytany o plany na przyszłość mówi: Czas pokaże. Do domu na pewno nie wróce [...] chciałbym nauczyć sie języka hiszpańskiego i gdzieś wyjechać. Gdzieś, gdzie jest słońce [śmiech] (IDI_3_27 lat). Znając biegle pięć języków (natywny azerski, rosyjski, turecki, angielski, polski) jest pewien, że w życiu sobie poradzi i zawsze znajdzie pracę.

Kolejna z respondentek (ma Kartę Polaka - dziadek był Polakiem) w wieku 25 lat, po roku pracy jako przedstawiciel farmaceutyczny i medyczny w kraju pochodzenia (wykształcenie wyższe, biologia), podjęła decyzję o wyjeździe do Polski (pod wpływem rozmowy z przyjaciółką studiującą w Białymstoku). Żywiła obawy, czy warto zaczynać od nowa, miała dobrą pracę (zagraniczne podróże do Gruzji, na Łotwę, Litwę, Ukrainę), relatywnie dobre warunki finansowe, mówi:

Czegoś mi brakowało. Zastanawiałam się czy to już [...] nikomu nic nie mówiłam, ale wystałam aplikacje na studia do Polski. Pomyślałam sobie, 5 lat tego wyksztatcenia, szkoda, że się nie przyda, ale spróbuję na magisterkę [...] Zastanawiałam się czy warto, 25 lat, prawie ułożone życie i zaczynać ponownie, ale nieważne, ile masz lat, zawsze się może udać (IDI_12_29 lat).

Obecnie ma partnera Polaka, pomaga bratu i jego rodzinie w przeprowadzce do Polski. Po ukończeniu studiów podyplomowych z dietetyki, planuje założenie biznesu związanego z konsultacją dietetyczną. 


\section{Sytuacja rodzinna migrantów mieszkających w Lodzi}

Analiza więzi rodzinnych, przyjacielskich oraz towarzyskich i ich wpływu na podjęcie decyzji migracyjnej, wskazuje na istotne znaczenie znajomości z osobą, która miała już za sobą doświadczenie migracyjne (11 osób przed wyjazdem $\mathrm{z}$ kraju pochodzenia miało kontakt $\mathrm{z}$ osobą przebywającą aktualnie w Polsce, a 6 osób z osobą mieszkającą wcześniej w Polsce lub w innym kraju europejskim). Trzech respondentów deklarowało, iż od najmłodszych lat marzyli o podróżowaniu, stałym wyjeździe z kraju. W tym celu we wcześniejszych latach życia uczyli się języków obcych (głównie języka angielskiego), brali udział w stażach, wymianie studenckiej i organizowali wyjazdy wakacyjne. $\mathrm{W}$ jednym $\mathrm{z}$ analizowanych przypadków liczne doświadczenia migracyjne rodziny pochodzenia (IDI_6_36 lat) od najmłodszych lat były przesłanką do poszukiwania miejsca na ziemi poza krajem i niespisana zgoda i zachęta rodziców na wyprowadzkę z kraju (IDI_6_36 lat). Część respondentów posiadała rodzeństwo mieszkające za granicą (głównie w Stanach Zjednoczonych, Kanadzie, Irlandii i Niemczech), co było deklaratywnie dodatkową motywacją i naturalnym sposobem na życie w momencie podejmowania decyzji o własnym wyjeździe.

Negatywny wpływ wyjazdu na relacje z rodziną pochodzenia ujawnił się w dwóch biografiach. Pochodzący z Kamerunu 30 letni mężczyzna wspominał reakcje rodziców na jego wyjazd:

Ojciec nie byt szczęśliwy z powodu mojego wyjazdu, jestem najstarszym i jedynym synem. Dla niego to było naturalne, że zostane i będe się opiekowat nim, domem i matka. Chciat mieć swojego jedynego syna na miejscu. Moje siostry też wyjechaty - jedna jest w Kanadzie, druga we Francji. Im ojciec wybaczyt, bo sa kobietami... ze mna miat $i$ wciąż ma problem [...] myślę, że w końcu to zaakceptowat, ale nie rozmawiamy często. Z mama kontaktuję się niemal codziennie, z ojcem bardzo rzadko [...] najczęściej pyta czy i kiedy wracam [śmiech] (IDI_14_30 lat).

Pochodzący z Francji trzydziestolatek (IDI_21_30 lat), przyjeżdżając do Polski na rok w ramach programu Erasmus, nie planował stałej przeprowadzki, ale znalezienie stałej partnerki (Polki) i dobrze płatnej pracy zarobkowej zaowocowało pobytem stałym. Jego rodzice sprzeciwili się tej decyzji, mówiąc o marnowaniu sobie życia, szans zawodowych oraz możliwości kariery w kraju pochodzenia. Sytuację potęgował fakt, iż jest on jedynakiem. Mimo iż zaakceptowali sytuację syna i synową, rzadko odwiedzają się (dwa razy do roku) i namawiają go do powrotu do Francji.

Danilewicz (2012) opisując zjawisko transnarodowości, tj. funkcjonowania migrantów poza granicami, bez zrywania kontaktów z ojczyzną, zwraca uwagę na bycie „tu i tam” i pełne uczestnictwo również w życiu rodzinnym. Waldinger (2008: 824, 826) „transmigrantami” określa „osoby, które po wyjeździe z jednego państwa do drugiego żyją ponad granicami tych państw, uczestnicząc w społecznych relacjach osadzających je jednocześnie w więcej niż jednym państwie narodowym". 
Ponad połowa badanych osób deklarowała codzienny kontakt z rodziną pochodzenia pozostałą w kraju/mieszkającą za granicą (najczęściej z rodzeństwem), głównie za pośrednictwem komunikatorów społecznościowych (Messenger; Viber i W kontakcie - dla Ukrainy i Białorusi; WhatsApp - dla krajów UE i reszty świata). Większość respondentów doceniała możliwość rozmowy za pomocą wideo czatów oraz ciągłą możliwość wysyłania zdjęć, co daje namiastkę bycia na miejscu(IDI_7_28 lat).

Grupowe konwersacje sq dobre. Mam kilka grup - bliska rodzina, rodzina ze strony mamy, rodzina ze strony ojca, tam też ciotki sa i przyjaciele [...] wszyscy caty czas prosza - wysyłaj zdjęcia, wysytaj zdjęcie [...] to raz wyślę i już wszyscy wiedzą. Kontakt jest $24 \mathrm{~h}$ na dobę. Zawsze ktoś odpisze, coś wyśle (IDI_11_35 lat).

Sytuację rodzinną respondentów obrazuje diagram 1. Większość osób będących w relacjach partnerskich, deklarowała chęć wstąpienia w związek małżeński, ale odkładała ten moment na później. Związki zarówno w obrębie tej samej grupy narodowej, jak i z obcokrajowcem, w tym Polakiem/Polką borykały się z podobnymi problemami dotyczącymi organizacji ślubu (wybór miejsca i finansowanie uroczystości, przyjazd rodziny i przyjaciół) oraz ważniejszymi potrzebami, które wymagają dużych środków finansowych - zakup wspólnego mieszkania (IDI_19_28 lat); rodzinny wyjazd na wakacje (IDI_15_28 lat) ${ }^{4}$.

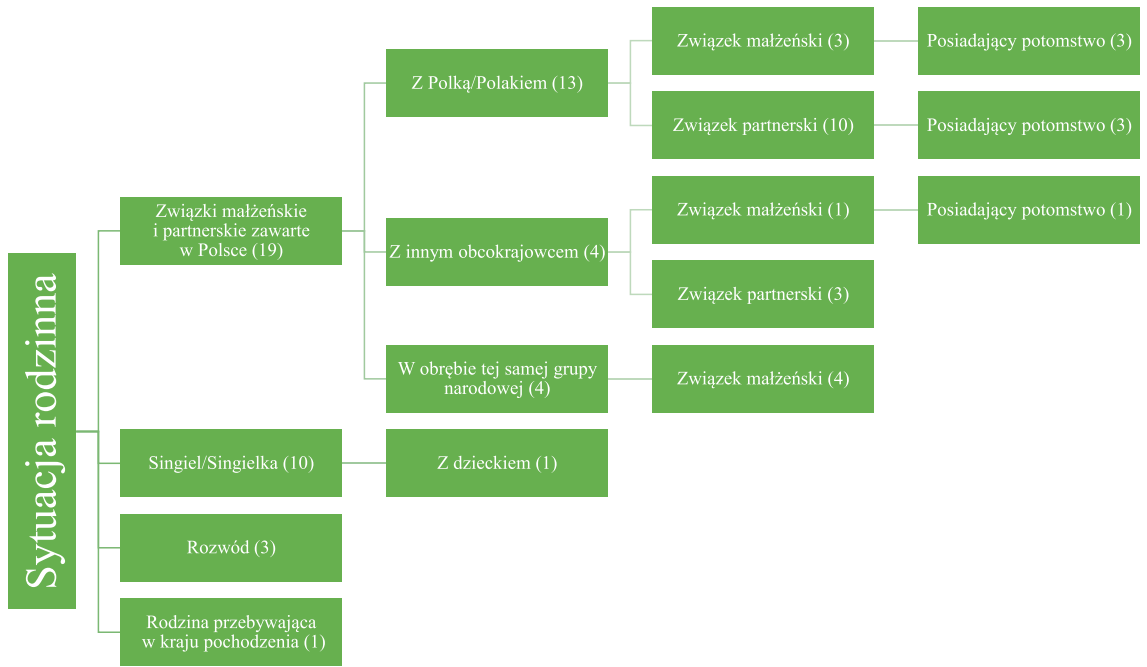

Diagram 1. Sytuacja rodzinna objętych badaniem migrantów mieszkających w Łodzi Źródło: opracowanie własne

${ }^{4}$ Zagadnienie wchodzenia w związki z przedstawicielami innych narodowości jest częstym obiektem badawczym, a prace Slany i Solgi (2014) oraz Kaczmarczyka (2014), ukazują, iż Polki najczęściej wychodzą za mąż za obywateli Wielkiej Brytanii, Niemiec, Włoch, Irlandii, Francji, Holandii. Natomiast Polacy najczęściej poślubiają obywatelki Ukrainy, Białorusi i Rosji. W badanej grupie respondentów trzy związki małżeńskie z Polkami zostały zawarte przez obywateli Szwajcarii, Włoch i Francji. Natomiast stałe związki z Polakami (4) stworzyły Białorusinki, Łotyszki i Ukrainki. 
Narodziny dzieci określane był przez większość z badanych jako moment przypieczętowania związków z Polską. Także nieposiadający jeszcze potomstwa, narodziny i wychowywanie dzieci wskazywali jako najwyższą formę osiedlenia i zapuszczenia korzeni: Polka się będę czuć dopiero, kiedy będę miata dzieci i będę im pomagać w szkole, lekcje odrabiać po polsku i one będa bardziej Polakami (IDI_12_29 lat).

Siedmioro z trzydziestu dwóch badanych stale wspiera finansowo rodzinę w kraju pochodzenia, przesyłając miesięcznie stałą kwotę oraz świadczy pomoc rzeczową (wysyłanie odzieży, produktów żywnościowych, prezenty podczas odwiedzin). Działania takie bezpośrednio przekłada się na społeczno-ekonomiczny poziom życia rodziny migranta $\mathrm{w}$ kraju pochodzenia i niejednokrotnie jest jedyną szansą utrzymania rodziny (IDI_30_29 lat, mężczyzna, rodzina w sytuacji rozłąki migracyjnej, niepracująca żona i dwoje dzieci przebywających na Ukrainie). Realnym wpływem na życie rodziny pochodzenia oraz przyjaciół pozostałych w kraju jest również odwiedzanie się (14 respondentów) przez członków rodziny, znajomych i przyjaciół. Kraj pobytu dzieci (i w czterech przypadkach wnuków) determinuje coroczne miejsce spędzania urlopu, świąt i ważnych uroczystości rodzinnych. Przyjaciele odwiedzający migrantów w Łodzi, są często zachwyceni Polską: nigdy z własnej woli by tu nie przyjechali, a dzięki Tobie wrócę na pewno nie raz (IDI_10_32 lata).

Codzienne życie większości migrantów koncentruje się wokół pracy zawodowej. Czas wolny wyznaczają systemy zmianowe i dni wolne w pracy (w szczególności u pracowników ukraińskich i białoruskich); pracownicy biurowi, mający wolne weekendy i wieczory, chętnie spędzają czas w restauracjach, pubach i korzystają z kulturalnej oferty miasta. Większość rozmówców deklarowała utrzymywanie kontaktów towarzyskich z kolegami i koleżankami z pracy - Polakami oraz innymi cudzoziemcami. Pracownicy Ukraińscy zatrudnieni w systemie zmianowym, biorący nadgodziny, często dorabiający w weekendy, wolny czas najczęściej poświęcają na odpoczynek, sen lub spędzają go z innymi przedstawicielami ukraińskiej diaspory - w miejscu zamieszkania (wspólne zamieszkiwanie) lub w najbliższej okolicy, korzystając z parków, wspólnie grillując, robiąc zakupy i przygotowując posiłki.

\section{Praktyki religijne migrantów w Lodzi}

Kontakty z rodziną pochodzenia utrzymywane są często przy okazji celebrowania ważnych życiowych momentów, świąt i uroczystości. Respondenci zróżnicowani byli według wyznania i praktyk religijnych, w równej części deklarując wyznanie rzymskokatolickie, prawosławne i islam. Pozostali byli ateistami, wyznawcami hinduizmu i ewangelizmu reformowanego. Kościół i wspólnota religijna odgrywają ważną rolę w życiu jednego respondenta (IDI_1_22 lata). 
Coniedzielne spotkania mają nie tylko wymiar religijny, ale również towarzyski i integracyjny - umożliwiają poznanie nowych osób.

Mieszkający w Łodzi muzułmanie nie narzekają na brak meczetu. Podczas ważnych uroczystości jadą do Warszawy (raz w roku, IDI_8_26 lat) oraz praktykują samodzielnie, a prowadzona przez Syryjczyków sala modlitw jest miejscem copiątkowych spotkań (IDI_5_36 lat) i okazją do poznania muzułmańskiej społeczności. Dwoje respondentów z Turcji (IDI_7_28 lat; IDI_27_25 lat) ujawnia liberalizację podejścia do wiary, nieprzestrzeganie diety (hallal) i brak potrzeb religijnych.

Ukraińcy mieszkający w mieście, choć praktykują inną religię (prawosławie) to bliskość tradycji i celebrowanych świąt (mimo odmiennego kalendarza) powoduje poczucie bycia u siebie (IDI_17_26 lat). W ważnych momentach jadą do cerkwi, znajdującej się w centrum miasta, a w sytuacjach „potrzeby serca” idą pomodlić się do kościoła.

Rozmówcy pochodzący z Włoch, wskazywali na zbieżne, w ich opinii, podejście Polaków i Włochów do religii katolickiej - podobnie celebrowane tradycje, bycie religijnym i coniedzielne chodzenie do kościoła umożliwiają kontynuowanie rodzinnych tradycji kraju pochodzenia.

\section{Dostęp do rynku pracy i zatrudnienie cudzoziemców w Lodzi}

Ujawniona w części analizowanych biografii mobilność zawodowa i łatwość dostosowania się do potrzeb rynku pracy często współwystępuje z pracą poniżej posiadanych kwalifikacji. Badania dotyczące ruchliwości migrantów na polskim rynku pracy (por. Grabowska-Lusińska, Jaźwińska 2012), prowadzone są najczęściej w ilościowym paradygmacie, często nie obejmują etapów kariery zawodowej, które mają istotny wpływ na jej przebieg, za to koncentrują się na przepływie ludności pomiędzy krajem wysyłającym a przyjmującym. Migrują najczęściej osoby w wieku mobilnym (18-44 lata), często są na początku kariery zawodowej, pierwszą pracę podejmując w kraju emigracji (taka sytuacja dotyczyła dużej części badanych osób). Rozmówcy z krajów UE i państw EOG najczęściej kwalifikowali się do grupy wysoce wykwalifikowanych pracowników, natomiast osoby pochodzące zza wschodniej granicy RP najczęściej pracowali poniżej własnych kwalifikacji, wykonując proste prace w sektorze usług i produkcji.

Respondenci wskazali na umiejętności językowe jako kluczowe w dostępie do rynku pracy. Brak doświadczenia zawodowego i kwalifikacji nie uznawano za przeszkody, a znajomość więcej niż jednego języka obcego (łącznie z natywnym) w trzech przypadkach była źródłem awansu zawodowego. Podjęcie decyzji migracyjnej dla pięciu osób badanych wiązało się z awansem i poprawą statusu zawodowego: Kiedy firma podjęła decyzję o otwarciu nowej fabryki w Polsce 
zostatem częścia zespołu [...] w Szwajcarii nie byłem team leaderem [...] lepsze warunki dostałem, jak powiedziatem, że zostanę na 4 lata (IDI_29_39 lat).

Choć dominującą formą zatrudnienia migrantów jest umowa o pracę (19 respondentów), duża ich grupa prowadzi w Polce własną działalność gospodarczą (por. Andrejuk 2016, 2017). Czterech respondentów prowadziło z sukcesem własne biznesy, zatrudniając pracowników - najczęściej tego samego pochodzenia etnicznego (IDI_18_28 lat) oraz Polaków (IDI_5_36 lat). Podejmowanie pracy na czarno zadeklarowało trzech respondentów, ich praca polegała na nauczaniu języka natywnego.

To jest dobrze. Ruszamy ekonomię [...] Sami pracowaliśmy też i Polaki pracowali z nami [...] trochę było pót na pót, wie pani, ponabijało się na czarno [...]. Polak przychodzi i nienawidzi wszystko na biało w pracy. Chce 50 na rękę, a 50 za rękaw, jak mówit pod stotem. Bo mówi, jak dostanie cata pensja to będzie mniej podatki na dzieci, to tu, to tu. Dla mnie bardzo dobrze jak znajdziesz pracownika na biało, bo to jest faktura. Ale nie znajdziesz pracownika, który jest uczciwy. Jak chcesz pracownika, to robisz mu, jak on chce (IDI 536 lat; mężczyzna opowiadający o nieistniejącym już biznesie, który działał przez 5 lat).

Badani wymienili następujące sposoby poszukiwania pracy:

- portale internetowe (28 respondentów - najczęściej portal pracuj.pl);

- polecenie przez znajomego (12);

- targi pracy (7) - główny sposób poszukiwania pracy przez studentów;

- kontynuacja zatrudnienia z kraju pochodzenia (2) przy otwarciu fabryki bądź oddziału w Łodzi, jako forma awansu i podwyżki wynagrodzenia.

Dla większości rozmówców Polska była pierwszym krajem emigracji (21), a Łódź pierwszym miejscem pobytu i zatrudnienia w Polsce. Część badanych przybyła z innych polskich miast: Białegostoku, Puław, Kielc, Gdańska, Warszawy, Katowic, Wrocławia.

Tylko co trzeci respondent wykonywał pracę zgodną z wykształceniem. Migranci z Ukrainy (5) i Białorusi (2) podejmowali pracę poniżej kwalifikacji (np. IDI_19_28 lat - ukończone studia wyższe, praca na produkcji w oparciu o umowę zlecenie; IDI_30_29 lat - praca naukowa w kraju pochodzenia, obecnie umowa o pracę jako kierownik brygadzistów). Sytuacja „utajonej deprecjacji” (Is ański 2015) czy „marnotrawstwa mózgów” (ang. brain waiste) (Danilewicz 2012) zakłada znalezienie w kraju pobytu pracy wymagającej niskiego poziomu kompetencji językowych (przy wysokich kompetencjach zawodowych), na pierwotnym rynku pracy, nieadekwatnie do umiejętności i wykształcenia. Mężczyzna pochodzący z Ukrainy (IDI_30_29 lat), w kraju pochodzenia zatrudniony jako naukowiec (archeologia), po przyjeździe do Polski pracował w sadownictwie, agencjach pośrednictwa pracy i jako brygadzista, a obecnie ma stanowisko kierowni-

${ }^{5}$ Szacunkowe dane wskazały, że liczba migrantów prowadzących własną działalność gospodarczą wzrosła o 55\% w porównaniu do roku 2012 (źródło: www.zus.pl [dostęp 20.07.2019]). 
cze i planuje pozostanie w firmie. Priorytetem jest dla niego przede wszystkim ekonomiczny wymiar pracy i możliwość dodatkowego zarobku (nadgodziny).

Jak szef zobaczyt, że jestem niepijacy, odpowiedzialny i ciężko pracuje, bo po to tu przyjechatem, to od razu miałem lepsze możliwości - więcej nadgodzin mogę robić (16 czasem nawet się i zdarza) [...] nie szukam lepszej pracy, bo ta jest dobra. Wiadomo, że zawsze lepiej tam, gdzie nas nie ma, jak to mówiq̨. Ale mi tutaj dobrze, jest ciężko, ale czuję, że chca mnie zatrzymać. Doceniają i czasem jakaś premia się też zdarzy (IDI_30_29 lat).

Takie podejście określane jest jako strategia „,pazerności na pracę” (Danilewicz 2012; por. Eade, Drinkwater, Garapich 2006; Kaczmarczyk 2006) lub strategia typu „chomik”. Koncepcja ta oznacza rodzaj zatrudnienia w nisko opłacanych sektorach, poniżej kwalifikacji, motywowany chęcią jak najszybszego zgromadzenia potrzebnego kapitału finansowego. Strategia odnoszona głównie do migracji krótkoterminowych i sezonowych, ujawnia się w szczególności wśród pracowników z Ukrainy i Białorusi. Wyrabianie pensum godzin, nadgodzin, podejmowanie dodatkowego zatrudnienia przy maksymalnej minimalizacji kosztów utrzymania - wiąże się z planem zaoszczędzenia konkretnej kwoty pieniędzy na zakup mieszkania, rozpoczęcie własnej działalności gospodarczej, wesele czy samochód.

Respondent pochodzący z Ukrainy (IDI_19_28 lat), będący w Polsce od pięciu lat, na pytanie o zarobki i sposoby spędzania czasu wolnego odpowiedział:

Pracować po pięć dni w tygodniu po 8 godzin to nic. Nic nie odtożysz. Jak teraz pracujemy po 12-16 godzin to wtedy coś możesz odłożyć. Jak chcesz zarobić, to tylko tak. [...] Jak już jesteśmy po pracy, to idziemy do innej pracy [śmiech], najczęściej tak...śsimy tylko, bo nie ma czasu (IDI_19_28 lat).

\section{Wzorce zamieszkania i mobilność przestrzenna migrantów w Lodzi}

Minimalizacja kosztów utrzymania wiąże się wprost z kolejnym wymienionym przez Edmonstona (Edmon ston 2013) obszarem życia - mieszkalnictwem. Opisany w literaturze "fenomen wielojednostkowych gospodarstw domowych" (Danilewicz 2012), cechuje strategie mieszkaniowe osób stanu wolnego, niespokrewnionych i początkowo niezwiązanych ze sobą ${ }^{6}$. Mniej rozbudowaną formą mieszkania migracyjnego jest wspólne zamieszkiwanie dwóch, maksymalnie trzech osób, motywowane głównie czynnikiem ekonomicznym, ale gwarantujące intymność, prywatność poprzez zajmowanie własnego pokoju i korzystanie z części wspólnych (kuchni, łazienki, rzadziej salonu). Praktyka ta częściej dotyczy znajomych z pracy, studentów, kolegów, osób znających się.

${ }^{6}$ Według Łukasiuk (2010: 104): „W mieszkaniu migracyjnym mieszkają zazwyczaj równoprawni współlokatorzy, zajmując po 1, 2 czy nawet 3 osoby poszczególne pokoje, prowadząc mniej czy bardziej wspólne życie i dzieląc się obowiązkami związanymi z utrzymaniem mieszkania”. 
Wspólne zamieszkanie z kolegami ze studiów, z pracy bądź zaprzyjaźnioną osobą deklarowało ośmiu respondentów. Współlokatora najczęściej znajdowano poprzez wspólnych znajomych lub za pomocą mediów społecznościowych. Czterech respondentów mieszka $\mathrm{z}$ nieznanymi sobie wcześniej osobami: Będziemy kombinować, żeby coś wynajać. Teraz to tylko po 200 ptacimy, ale się nie da. Wspólna kuchnia jest trudna. Kłóca się wszyscy, bo na jednej zmianie pracuja i jest trudno, trudno mieszkać (IDI_20_23 lata).

Samodzielne lub dzielone z partnerem/małżonkiem mieszkanie deklarowało 13 respondentów. Część respondentów doświadczyła problemów ze znalezieniem mieszkania w Łodzi, zdarzały się sytuacje, w których niektórzy wynajmujący odmawiali wynajmu obcokrajowcom: Powiedzieli, że nie, jak się zorientowali, że nie jestem Polakiem (IDI_2_34 lat); Żadnych obcokrajowców (IDI_8_26 lat).

$\mathrm{Na}$ zakup mieszkania decydują się osoby dłużej przebywające w Polsce. Duża grupa respondentów deklarowała chęć pozostania w Łodzi, nieliczni (4) zamierzają wrócić do kraju pochodzenia, po zrealizowaniu postawionych celów (np. zdobyciu międzynarodowego doświadczenia zawodowego IDI_26_25 lat; IDI 8_26 lat). Pozostali rozważają opcję emigrowania do innego, dużego miasta w Polsce (najczęściej do Warszawy, Wrocławia lub Krakowa) oraz za granicę (do Niemiec, Irlandii, Kanady, Stanów Zjednoczonych, Wielkiej Brytanii). Część rozmówców nie precyzowała planów, uzależniając przyszłe decyzje od sytuacji rodzinnej, zawodowej i ekonomicznej: Pochodze z dużego miasta. Jak miałbym zostać w Polsce, to tylko tam, gdzie się coś dzieje, np. w Warszawie. Mam tam znajomych, czasem jeżḋę i to zupetnie inny świat (IDI_7_28 lat).

\section{Podsumowanie}

Analiza funkcjonowania migrantów w różnych obszarach życia społecznego, zawodowego i rodzinnego ma nie tylko poznawczo-eksploracyjny charakter, ale również wymiar aplikacyjny. Stanowi opis wyzwań, szans i zagrożeń codziennego funkcjonowania migrantów w odniesieniu do ich wieku oraz potrzeb i tym samym może być przesłanką do tworzenia polityki integracyjnej miasta i regionu, ze szczególnym uwzględnieniem wsparcia instytucjonalnego.

Zastosowana perspektywa przebiegu cyklu życia w połączeniu z koncepcją obszarów funkcjonowania migrantów w kraju ich pochodzenia i przybycia pozwoliła ujawnić złożoność ich doświadczeń życiowych. Obejmują one wybory życiowe oraz towarzyszące im trudności i sposoby ich przezwyciężania. Biografie badanych ujawniły zróżnicowanie dróg prowadzących do decyzji o zmianie miejsca pobytu, w tym decyzji o zamieszkaniu w Łodzi oraz ich związki z wiekiem, sytuacją rodzinną, realiami na rynku pracy oraz warunkami społeczno-ekonomicznymi i politycznymi w kraju pochodzenia. 


\section{Bibliografia}

Andrejuk K. (2016), Co skłania imigrantów do zakładania własnych firm? Analiza procesu samozatrudnienia i rozwijania przedsiębiorstw etnicznych na przykładzie społeczności Ukrainców w Polsce, ,Studia Migracyjne - Przegląd Polonijny”, nr 3.

Andrejuk K. (2017), Self-employed Migrants from EU Member States in Poland: Differentiated professional trajectories and explanations of entrepreneurial success, ,Journal of Ethnic and Migration Studies", $\mathrm{nr}$ 43(4).

Arnett J.J. (2004), Emerging Adulthood: The winding road from the late teens through the twenties, Oxford University Press, New York.

Arnett J.J. (2007), Adolescence and Emerging Adulthood: A cultural approach, Pearson Education, New Jersey.

Arnett J.J., Tanner J.L. (2005), Emerging Adults in America: Coming of age in the 21st century, American Psychological Association Press, Washington.

Bernhardt E. et al. (2007), Immigration, gender, and family transitions to adulthood in Sweden, University Press of America, Lanham.

Blau P.M., Duncan O. (1967), The American Occupational Structure, John Wiley and Sons, New York.

Bonifazi C. et al. (red.) (2008), International migration in Europe; new trends and new methods of analysis, IMISCOE Research, Amsterdam University Press, Amsterdam.

Danilewicz W. (2012), Wybrane cechy i strategie poakcesyjnych migracji z Polski, „Warmińsko-Mazurski Kwartalnik Naukowy", nr 1.

De Valk H.A.G. (2006), Pathways into adulthood. A comparative study on family life transitions among migrant and Dutch youth, University Utrecht, ICS dissertation series, Thela thesis, Utrecht:

Drinkwater S., Eade J., Garapich M. (2006), Poles Apart? EU Enlargement and the Labour Market Outcomes of Immigrants in the United Kingdom, „International Migration”, nr 1(47).

Duncan O., Featherman D., Duncan B. (1972), Socioeconomic Background and Achievement, Seminar Press, New York.

Edmonston B. (2013), Lifecourse Perspectives on Immigration, „Immigration and the Life Course", special issue, Canadian Studies in Population, nr 40(1-2).

Elder G.H. (1985), Perspectives on the Life Course, [w:] G.H. Elder (red.), Life Course Dynamics. Transitions and Trajectories, 1968-1980, Cornell University Press, Ithaca.

Elder G.H. (1994), Time, Human Agency, and Social Change: Perspectives on the life course, „Social Psychology Quarterly”, t. 57.

Elder G.H (1998), The Life Course as Development Theory, „Child Development”, t. 69.

Elder G.H., Caspi A. (1990), Studying Lives in a Changing Society: 28 Sociological and Personological Explorations, [w:] A.I. Rabin, R. Zucker, R. Emmons, S. Frank, Studying Persons and Lives, Springer, New York.

Erikson E. (2004), Tożsamość a cykl życia, Zysk i S-ka, Poznań.

Gennep A. van (2006), Obrzędy przejścia, Państwowy Instytut Wydawniczy, Warszawa.

Glick P.C. (1988), Fifty Years of Family Demography: A record of social change, „Journal of Marriage and the Family", t. 50.

Grabowska-Lusińska I., Jaźwińska E. (2012), Mobilność przestrzenna, społeczna i kariery zawodowe migrantów. Cele, problemy i podejścia badawcze na podstawie badań OBM UW, „Studia Migracyjne - Przegląd Polonijny”, z. 2.

Grabowska-Lusińska I., Okólski M. (2009), Emigracja ostatnia?, Wydawnictwo Naukowe Scholar, Warszawa. 
Grotowska-Leder J., Rek-Woźniak M., Kudlińska I. (2016), Polityka przebiegu życia teoretyczne i metodologiczne ramy badań nad procesem osiagania dorostości, „Przegląd Socjologiczny", t. LXV, nr 2.

Hagan J., Mcmillan R., Wheaton B. (2018), New Kid in Town: Social capital and the life course effects of family migration on children, „American Sociological Review”, t. 61.

Henretta J. (2003), The Life Course Perspective on Work and Retirement, [w:] R.A. Settersten Jr. (red.), Invitation to the Life-course: Toward new understandings of later life, Baywood Amityville, New York.

Isański J. (2015), Migracje i transfery kapitalu społecznego, Wydawnictwo Uniwersytetu Adama Mickiewicza, Poznań.

Jasso G. (2002), Migration, Human Development, and the Life Course, [w:] J. Mortimer, M. Shanahan (red.), Handbook of the Life Course, Kluwer Academic Publishers, New York.

Jasso G. (2003), Migration, Human Development, and the Life Course, [w:] J. Mortimer, M. Shanahan (red.), Handbook of the Life Course, Kluwer Academic/Plenum Publishers, New York.

Kaczmarczyk P. (2006), Wspótczesne migracje zagraniczne Polaków - skala oraz potencjalne skutki dla rynku pracy, Raport OBM, Warszawa.

Kaczmarczyk P. (red.), (2014), Recent Trends in International Migration in Poland. The 2012 SOPEMI Report, „CMR Working Papers”, nr 71(129).

Kalmijn M., van Tubergen F. (2006), Ethnic intermarriage in the Netherlands: Confirmations and refutations of accepted insights, „European Journal of Population”, nr 22.

Kohli M. (2007), The Institutionalization of the Life Course: Looking back to look ahead, „Research in Human Development", nr 4(3-4).

Kulu H., Milewski N. (red.) (2007), Interdependencies in the life course: Family, fertility, and migration (demographic research, special collection 6), MPIDR, Rostock.

Łukasiuk M.(2010), Wspótczesne mieszkanie migracyjne w kontekście teorii wsparcia społecznego, „Przegląd Socjologiczny”, t. LIX, nr 4.

Marshall V., Mueller M. (2003), Theoretical Roots of the Life Course Perspective, [w:] W. Heinz, V. Marshall (red.), Sequences, Institutions and Interrelations over the Life Course, Aldine de Gruyter, New York.

Mortimer J., Shanahan M. (red.) (2002), Handbook of the Life Course, Kluwer Academic Publishers, New York.

O'Rand A.M., Henretta J.C. (1999), Age and Inequality: Diverse pathways through later life, Westview Boulder, CO.

Paleczny T. (2002), Osobowościowe typy reakcji na zderzenia kultur w procesie emigracji, „Studia Etnograficzne i Antropologiczne", t. 6.

Riley M.W., Riley J.W. (1994), Structural Lag: Past and future, [w:] M.W. Riley, R.L. Kahn, A. Foner (red.), Age and Structural Lag, Wiley, New York.

Slany K., Solga B. (red.) (2014), Społeczne skutki poakcesyjnych migracji ludności Polski. Raport Komitetu Badań nad Migracjami Polskiej Akademii Nauk, Warszawa.

Thomas W., Znaniecki F.W. (1958), The Polish Peasant in Europe and America, 2 vols, Dover, New York.

Waldinger R. (2008), Between Here and There: Immigrant cross border activities and loyalties, „International Migration Review”, nr 40(1).

Waniek K. (2015), „Ucieczka do...” jako istotna przyczyna mobilności w Europie, „Acta Universitatis Lodziensis Folia Sociologica", nr 53(31).

Wheaton B. (1990), Life Transitions, Role Histories, and Mental Health, „American Sociological Review", nr 55(2). 
Wingens M., Windzio M., de Valk H., Aybek C. (2011), A Life-Course Perspective on Migration and Integration, Springer Dordrecht, Heidelberg-London-New York.

Wrzesień W. (2009), Europejscy poszukiwacze, Wydawnictwo Naukowe PWN, Warszawa.

Jagoda Przybysz

\title{
THE EXPERIENCE OF MIGRATION IN THE BIOGRAPHIES OF IMMIGRANTS LIVING IN LODZ
}

\begin{abstract}
The article is a qualitative analysis of 32 biographies of immigrants living in Lodz for at least 3 years, in the theoretical framework of "life course studies". Individual stories of foreigners are analyzed in the context of their life choices, the moments of their life stages, the impact of social conditions, social networks and the decision to migrate and move to another country (made in the country of origin) and about favorable and unfavorable factors that decide about staying in Poland, continuing education, finding a job and starting a family.
\end{abstract}

Keywords: life course, migration, reasons of migration, effects of migration, immigrants, Łódź. 